\title{
IMPACT FINANCIAL PERFORMANCE TO STOCK PRICES: EVIDENCE FROM INDONESIA
}

\author{
Indra Prasetyo, Universitas Wijaya Putra \\ Nabilah Aliyyah, Universitas Wijaya Putra \\ Rusdiyanto, Universitas Airlangga
}

Diah Rani Nartasari, Akademi Sekretari dan Manajemen Indonesia Surabaya

Sanjayanto Nugroho, Akademi Sekretari dan Manajemen Indonesia Surabaya

Yessi Rahmawati, Akademi Sekretari dan Manajemen Indonesia Surabaya

Selvi Permata Groda, Akademi Sekretari dan Manajemen Indonesia Surabaya

Surya Setiawan, Akademi Sekretari dan Manajemen Indonesia Surabaya Bigraf Triangga, Akademi Sekretari dan Manajemen Indonesia Surabaya

Eko Mailansa, Akademi Sekretari dan Manajemen Indonesia Surabaya Gusti Dian Prayogi, Akademi Sekretari dan Manajemen Indonesia Surabaya

Niki Etruly, Akademi Sekretari dan Manajemen Indonesia Surabaya Muhamad Jazuli, Akademi Sekretari dan Manajemen Indonesia Surabaya

Nila Dewi Wahyuningsih, Akademi Sekretari dan Manajemen Indonesia Surabaya

Nunik Dwi Kusumawati, Akademi Sekretari dan Manajemen Indonesia Surabaya

Satunggale Kurniawan, Akademi Sekretari dan Manajemen Indonesia Surabaya

Indira Nuansa Ratri, Akademi Sekretari dan Manajemen Indonesia Surabaya

Wiyono Atmojo, Akademi Sekretari dan Manajemen Indonesia Surabaya Yuventius Sugiarno, Akademi Sekretari dan Manajemen Indonesia Surabaya

Danny Koerniawan Pamungkas, Akademi Sekretari dan Manajemen Indonesia Surabaya

Ahmad Muslim, Akademi Sekretari dan Manajemen Indonesia Surabaya Muhammad Afifi Rahman, Akademi Sekretari dan Manajemen Indonesia Surabaya

Nawang Kalbuana, Politeknik Penerbangan Curug

Arif Syafi'ur Rochman, Universitas Gresik 


\begin{abstract}
The authors propose in this study to evaluate financial performance applications for stock prices of the Indonesian Stock Exchange in manufacturing companies. The method of research used here is a quantitative descriptive method. In that statement, Indonesian Stock Exchange manufacturing companies between 2016 and 2018 are the population use in this research, using the sampling technique Purpose Sampling. This research uses secondary data from 2016 to 2018, the financial reports of Indonesian Stock Exchange manufacturing companies. The Indonesian stock exchange web site has been provided with all data sources at https://www.idx.co.id, and searching for www.google.id. Our analysis shows that book value prices and the net profit margin affect stock prices. The value of financial performance at the Indonesian Stock Bourses manufacturing companies' cost amounts to 64.5 percent, while other factors not listed in this study account for 35.4 percent.
\end{abstract}

Keywords: Stock Prices, Financial Performance

JEL Classification: O10, O14, A12, C11, C12

\title{
INTRODUCTION
}

Financial understanding means the assessment of the financial condition or the company's performance; the analysis needs several ratio and index benchmarks used which link two financial data one from the next (Al-ahdal et al., 2020; Bourke et al., 2020; Liu, 2020; Lussak et al., 2020). For investors, information about the performance of the company can use to see if you maintain your company investments or look for alternative solutionsGood performance of the company, high business value, Investors are seeing the company invest its capital to increase share prices to high business value.

There are several contributions from this study. The results of this research identified the importance of current problems in Indonesia, The implementation of financial performance has a positive impact the company's stock price in Indonesia, which focuses appropriately on manufacturing companies' operations. Our findings indicate that the application of financial performance has an Influence on manufacturing companies' stock prices. Thus this research expands our knowledge financial performance at inventory prices of Indonesian manufacturing companies.

The research is organized accordingly; formulation of relevant research, development of hypotheses, sample explanations, variables, and empirical models; Empirical analysis and results; the findings and implications of the research.

\section{LITERATURE AND DEVELOPMENT OF HYPOTHESIS}

\section{Stewardship Theory and Agency Theory}

Stewarship theory is based on philosophical hypothesis of human nature, in essence, humans can trust, act responsibly, be honest and honest with others. This is implicated in the desired trust by shareholders (Cater et al., 2019; Chrisman, 2019; Pacheco, 2019; Till \& Yount, 
2019). In other words, the theory of stewardship considers management to be confident in acting best for general public interests and in particular for investors.

Agency theory developed by (Jensen\&Meckling, 1976), explains that management as a shareholder's agent is not to act as a sophisticated and fair shareholder party to shareholders as assumed in the management model, with awareness for their own interests. Contrary to the theory of stewardship, agency theory believes that management cannot be trusted to act as it is in general or in particular to serve the public interest. Thus, managers cann't trusted to do their jobs - which of course is to maximize shareholder value.

\section{Stock price}

Stock prices can change up to or down in a quick count of time and can even change in seconds or minutes. The share price is the price that occurs at some point possible due to the supply and demand among the buyer and the seller of the stock. Certain circumstances and situations that can change stocks include the company's policy on expansion including micro and macroeconomic conditions, such as opening agencies, branches both at home and abroad; a sudden change in the position of manager or commissioner of the company involved in criminal acts and cases (Hapsoro \& Husain, 2019; Haris et al., 2019; Le et al., 2020; Sharma et al., 2020).

\section{Company Financial Performance}

Performance of the company may be assessed through various indicators or variables measuring the company's success; in general the company focuses on performance information derived from financial statements keuangan (Al-ahdal et al., 2020; Bourke et al., 2020; Liu, 2020; Lussak et al., 2020). These financial statements help investors, potential investors, creditors, and other users to decide investments, credit decisions, the analysis of shares and the future prospects of a company. The company's performance appraisal is carried out aimed at motivating employees in achieving organizational goals and in complying with predetermined standards of behavior in order to achieve good corporate goals. Through performance appraisals, companies can choose strategies and its financial structure.

Financial ratios are the most commonly used financial analysis tools. The ratio can be understood as the results obtained from one amount to another. The financial ratio analysis is a performance analysis instrument which describes various relationships but also financial indicators intended to demonstrate changes in the financial or business conditions of previous operations and to illustrate trends of such change patterns, thus showing risks and opportunities innate in the business concerned (Boisjoly et al., 2020; Khoja et al., 2019; Lončarski \& Vidovič, 2019; Sun et al., 2019). The ratio describes a relationship or symbol between a certain amount with another amount, and by using analytical tools as a ratio that will explain or illustrate to the analyzer whether the good or bad condition of the financial position in the company.

\section{Research Framework}




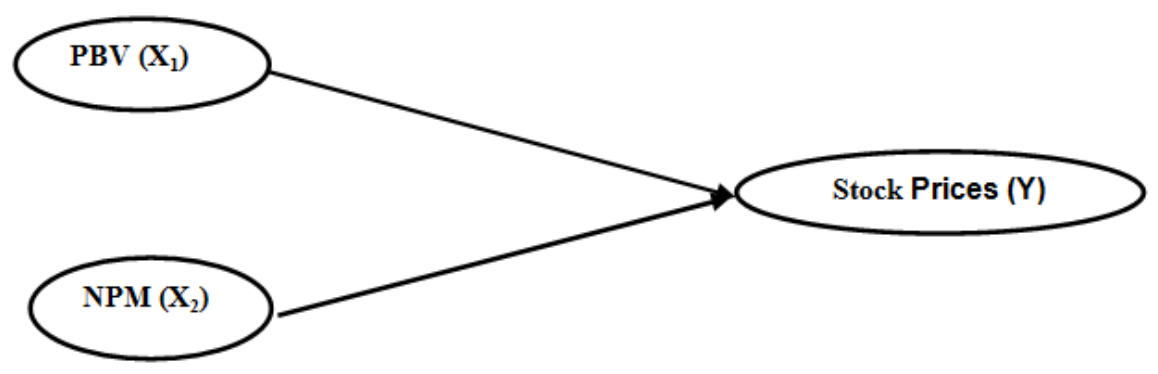

\section{FIGURE 1 \\ RESEARCH FRAMEWORK}

\section{The Financial Performance Effect On Stock Prices}

Company's financial performance is instrumental and fundamental to be known to investors because they can see the share price in the future. Company's financial performance the impact on stock prices is significant and positive. The better the financial performance of the company, The number of investors who are interested and need buy stock in the enterprise leads to higher share prices. The research has been supported by (Al-ahdal et al., 2020; Bourke et al., 2020; Liu, 2020; Lussak et al., 2020) who showed that the financial performance of the company were significantly impact of stock prices on Indonesian stock exchange manufacturing companies. The financial financial performance of the company can affect share prices in stock trading, investors are always concerned about the growth in the company's financial performance so that it can affect stock price growth and fall.

$\mathrm{X} 1$ : The financial performance of the company affects the stock price

\section{METHODS OF RESEARCH}

\section{Type of Approach to Research}

This research type uses quantitative research Based on positivism philosophy in certain groups or samples, collection of data, analysis of quantitative and statistical data, using research instruments to test hypotheses which were set. The descriptifying approach is to determine an independent variable's existence on one or several variables and search variables in relation to other variables determined (Juanamasta, Wati, Hendrawati, Wahyuni, Pramudianti, Wisnujati, Setiawati, Susetyorini, Elan, Rusdiyanto, Muharlisiani, et al., 2019; Luwihono, Suherman, Sembiring, Rasyid, Kalbuana, Saputro, Prasetyo, Taryana, Suprihartini, Asih, et al., 2021; Prabowo et al., 2020b; Rusdiyanto, Agustia, et al., 2020; Rusdiyanto, Hidayat, et al., 2020; Shabbir et al., 2021; Susanto, Prasetyo, Indrawati, Aliyyah, Rusdiyanto, Tjaraka, Kalbuana, Syafi'ur Rochman, et al., 2021), (Juanamasta, Wati, Hendrawati, Wahyuni, Pramudianti, Wisnujati, Setiawati, Susetyorini, Elan, Rusdiyanto, Astanto, et al., 2019), (R. Rusdiyanto \& Narsa, 2019), (Gazali, Kusuma, Aina, Bustaram, Amar, et al., 2020), (Syafii et al., 2020), (Lamtiar et al., 2021), (Gazali, Kusuma, Aina, Bustaram, Risal, et al., 2020), (Rusdiyanto, Sawarjuwono, et al., 2020), (Shabbir et al., 2021), (Susanto, Prasetyo, Indrawati, Aliyyah, Rusdiyanto, Tjaraka, Kalbuana, Rochman, et al., 2021), (Luwihono, Suherman, Sembiring, Rasyid, Kalbuana, Saputro, Prasetyo, Taryana, Suprihartini, \& Asih, 2021), (Rahayu et al., 
2020), (Utari et al., 2020), (Prabowo et al., 2020a), (Astanto et al., 2020), (H. T. Rusdiyanto et al., 2020), (Rusdiyanto, Sawarjuwono, et al., 2020), (H1dayat et al., 2020), (Rusdiyanto \& Narsa, 2020), (Ulum et al., 2020), (R. Rusdiyanto et al., 2019), (Hidayat et al., 2020), (Zainurrafiqi et al., 2020), (Zainurrafiqi et al., 2020), (Hadi Susanto et al., 2021), (Woro Utari et al., 2020), (Susanto, Prasetyo, Indrawati, Aliyyah, Rusdiyanto, Tjaraka, Kalbuana, Rochman, et al., 2021).

\section{Definition of Variable Operations}

Theoretically, the operational definition of a variable is an element of research that provides an explanation or explanation of the operational variables so that they can be observed or measured.

\section{Independent Variabel (X)}

\section{Price to Book Value $\left(\mathrm{X}_{1}\right)$}

This ratio is useful to measure the ability of management in creating market value that exceeds investment cost expenditure. Rating ratios are the most complete measure of company performance, because they reflect risk ratios and return ratios (Indrayono, 2019; Kristanti \& Iswandi, 2019). This ratio is very important because the ratio is directly linked to the objective to maximize the company's value and the shareholders' wealth. The formula for calculate the Price to Book Value value is as follows:

$$
\mathrm{PBV}=\frac{\text { Market } \text { Price } \text { Per Share }}{\text { Book Value Per Share }}
$$

\section{Net Profit Margin $\left(\mathbf{X}_{2}\right)$}

It is the company sales ability to make a profit (Smart et al., 2019; Tee, 2019). The formula used to calculate Net profit margin is as follows:

$$
\mathrm{NPM}=\frac{\text { Earning after taxes }}{\text { Net Sales }}
$$

\section{Dependent Variable (Y)}

Stock price is the variable dependent in this research, its Stock price is equity proof value interest in a stock exchange limited liability company in which the shares are now circulating. Prices of stock may also be described as prices formed by interactions with both buyers and sellers of shares that are motivated by company profit expectations (Rusdiyanto \& Narsa, 2019; Syafii et al., 2020).

\section{Population and Sample}

The study includes manufacturers' financial statements on the Indonesian bursary in 2016-2018. Manufacturing companies' financial statements found on the Indonesian bourse in 2016-2018 are the sample in this study. 


\section{Data Analysis Method}

This study's analysis method is use to determine the effects of the independent single variables, depending variable by multiple linear regression analyses. Furthermore, to detect how much influence the independent variable has and to predict its value. Two or more for multilinear regression separate variables entered with in model are used. The linear regression multiple equations with three separate variables are as follows: in this study, the method of analyzing the effect of the two or more separate variables on each dependent variable is determined by means of a multilinear regression analysis. Furthermore, it is proposed to determine how much the value of independent variables affects and predicts it. The linear regression multiple equation with three different variables is as follows:

$$
\mathrm{HS}=\beta 0+\beta_{1} \mathrm{PBV}+\beta_{2} \mathrm{NPM}+\varepsilon_{1} \mathrm{t}
$$

\section{RESULT AND DISCUSSION}

\section{Test Result}

Descriptive Statistics reveal information about the characteristics and variables of financial performance from the perspective of Price to Book Value and Net Profit Margin. Data is taken from sample companies during the period 2016 - 2018. Descriptive statistics for the research variables can be seen as follows:

\begin{tabular}{|c|c|c|c|c|}
\hline \multicolumn{5}{|c|}{ TABLE 1 } \\
\hline DESCRIPTIVE STATISTICS TEST RESULTS \\
\hline Description & Minimum & Maximum & Mean & Std. Deiation \\
\hline Price book value & 0.07 & 46.63 & 3.3926 & 6.87296 \\
\hline Net profit margin & 0.01 & 1.55 & 0.119 & 0.18666 \\
\hline Stock Prices & 0.5 & 68650 & $6.7717 \mathrm{E} 3$ & 13692.18076 \\
\hline
\end{tabular}

The table above shows that the value of the standard deviation of the stock price variable is greater than the average value compared to other variables. This shows the stock price variable isn't good enough. Stock price data has an average value of stock prices of $6.7717 \mathrm{E} 3$, with a minimum value of 0.50 which is at PT. Indo Acidatama. Inc, while the maximum value is 68650 located at PT. HM. Sampoerna Inc. While the standard deviation of 13692.18. Shows relatively large data deviations, because the value exceeds the average value.

Price book value data has average value 3.3926, with a minimum value of 0.07 located at PT. Jaya Pari Steel Inc. while the maximum value is 46.63 in PT. Unilever Inc. While the standard deviation is 6.87296 which shows a relatively larger data deviation, therefore this data is not good enough.

Net profit margin data has average value 0.1190, with a minimum value of 0.01 located at PT. Pyridam Farma Inc. while the maximum value is 1.55 at PT. Budi Starch \& Sweetener Inc. While the standard deviation is 0.18666 which indicates a relatively larger data deviation, therefore this data is not good enough. 


\section{Results of A Multilinear Regression Analysis}

\begin{tabular}{|c|c|c|c|}
\hline \multicolumn{4}{|c|}{ TABLE 2 } \\
RESULTS OF A & MULTILINEAR REGRESSION ANALYSIS \\
\hline Variable & B & Std.Error & Sig t \\
\hline Constant & 9.111 & 1.052 & 0.000 \\
\hline Price Book Value & 0.680 & 0.186 & 0.001 \\
\hline Net Profit Margin & 0.815 & 0.155 & 0.000 \\
\hline
\end{tabular}

The results of the above analysis show that the independent variable price book value and net profit margin have the effect of the stock prices with the mathematical equation as follows:

$$
\mathrm{Y}=9.111+0.680 \mathrm{X}_{1}+0.815 \mathrm{X}_{2}+\varepsilon
$$

The fourth hypothesis test results showed the book value of the price had significant and positive impact on the share price. The fourth hypothesis was accepted, which indicated it had significant and positive impact on the stock price. The fifth hypothesis testing results show that Net profit margin affects stock prices positively and significantly, so the fourth hypothesis is accepted.

\section{Determination Coefficient Test Results $\left(\mathbf{R}^{2}\right)$}

\begin{tabular}{|c|c|c|c|c|}
\hline \multicolumn{5}{|c|}{ TABLE 3 } \\
\hline Model & R & R Square & Adjusted R Square & Std. Error of the Estimate \\
\hline 1 & 0.804 & 0.646 & 0.616 & $1,11,339$ \\
\hline
\end{tabular}

Based on the Model Summary regression analysis table in the $\mathrm{R}$ square column, the values are obtained $\mathrm{R}^{2}$ (R Square) of $64.6 \%$. This value indicates that the percentage of the relationship between the influence of independent variables (independent price book value and net profit margin on stock prices is $64.6 \%$. Or the variation of the independent variables used in the independent price book value and net profit margin) can explain $64.6 \%$ of the variation in the share price variable. While the remaining $35.4 \%$ is Influenced or stated by other variables not included in this model of research.

\section{Simultaneous Significance Test Results (Statistical Test-F)}

\begin{tabular}{|c|c|c|c|c|c|}
\hline \multicolumn{7}{|c|}{ TABLE 4 } \\
\hline Model & Sum of Squares & Df & Mean Square & F & Sig \\
\hline Regression & $1,33,678$ & 5 & 26,736 & 21,567 & $0.00 \mathrm{a}$ \\
\hline Residual & 73,138 & 59 & 1,240 & & \\
\hline To & $2,06,817$ & 64 & & & \\
\hline
\end{tabular}

F test results obtained results that the value of $\mathrm{F}=21,567$ with a value of significance $=$ 0,000 ( $\mathrm{p}$ value $<0.05$ ), which means that the independent price book value and net profit margin effects significantly on stock prices. 


\section{Significance Test Results for Individual Parameters (Test Statistics-t)}

\begin{tabular}{|l|c|c|}
\hline \multicolumn{3}{|c|}{ TABLE 5 } \\
\hline \multicolumn{2}{|c|}{ RESULTS OF STATISTICAL TEST-T } \\
\hline Variable & $\mathbf{t}$ & Sig \\
\hline Price book value & 3.657 & 0.001 \\
\hline Net profit margin & 5.26 & 0 \\
\hline
\end{tabular}

The result of the t-test will be obtained: The fourth hypothesis is obtained t-value $=3.657$ with a value of significance $=0.001$ ( $\mathrm{p}$ value $<0.05)$, which means the price book value positively and significantly affects stock prices. Thus, the fourth hypothesis is accepted. The fifth hypothesis is obtained t-value $=5.260$ with a value of significance $=0.000$ ( $\mathrm{p}$ value $<0.05$ ), Net profit margin impacts stock prices positively and significantly. Thus, the fourth hypothesis is accepted.

\section{DISCUSSION}

\section{The Effect of Price Book Value on Stock Prices}

From the analysis output above obtained a significant level of t-test $=0.000<\alpha=0.050$ (level of significance). Thus the effect of price book value on stock prices is partially significant. Because the regression results indicate a value of significance of 0.001 is smaller than $\alpha=0.05$. It can be concluded that the price book value affects the stock price.

\section{The Effect of Net Profit Margin on Stock Prices}

From the result of the analysis output above obtained a significant level of t-test $=0.000$ $>\alpha=0.050$ (level of significance). Thus the impact on stock prices of net profit margins is partially insignificant. Because the regression results show a value of significance 0.000 being smaller than $\alpha=0.05$. It can be concluded that net profit margin affects stock prices.

\section{CONCLUSIONS}

The effect of price book value has an impact on stock prices at a probability value of 0.001 less than $\alpha=0.05$, the effect of net profit margin has an influence on share prices with a probability value of 0,000 less than $\alpha=0.05$. The results of the $F$ test analysis showed that the value of $F=21.567$ with a significance value $=0.00$ with a value of $p<0.05$ ), this means that the independent price book value and net profit margin have an impact on stock prices. The influence of independent price book value and net profit margin can explain $64.6 \%$ of the share price. While the remaining $35.4 \%$ is influenced Other variables that have not been included in this study. 


\section{REFERENCES}

Al-ahdal, W.M., Alsamhi, M.H., Tabash, M.I., \& Farhan, N.H.S. (2020). The impact of corporate governance on financial performance of Indian and GCC listed firms: An empirical investigation. Research in International Business and Finance, 51.

Astanto, D., Rusdiyanto, M.F., Khadijah, S.N., Rochman, A.S., \& Ilham, R. (2020). Macroeconomic impact on share prices: evidence from indonesia. Solid State Technology, 63(6), 646-660.

Boisjoly, R.P., Conine T.E.J., \& McDonald M.B.I.V. (2020). Working capital management: Financial and valuation impacts. Journal of Business Research, 108, 1-8.

Bourke, J.G., Izadi, J., \& Olya, H.G. (2020). Failure of play on asset disposals and share buybacks: Application of game theory in the international hotel market. Tourism Management, 77.

Cater, J., James, K., Kidwell, R., Camp, K., \& Young, M. (2019). HRM practices and effectiveness: a comparison of US Hispanic and non-Hispanic family firms. Journal of Small Business and Enterprise Development, 26(5), 726-746.

Chrisman, J.J. (2019). Stewardship Theory: Realism, Relevance, and Family Firm Governance. Entrepreneurship: Theory and Practice, 43(6), 1051-1066.

Gazali., Kusuma, A., Aina, M., Bustaram, I., Amar, S.S., Rusdiyanto., Tjaraka, H., \& Panjilaksana, S.D.D. (2020). The Effect of Financial Performance on Stock Prices: a Case Study of Indonesian. Talent Development and Excellence, 12(1), 40074016.

Gazali., Kusuma, A., Aina, M., Bustaram, I., Risal, Z., Purwanto., Rusdiyanto., \& Tjaraka, H. (2020). Work Ethics of Madura Communities in Salt Business : A Case Study Indonesian. Talent Development and Excellence, 12(1), 3537-3549.

Hadi, S., Prasetyo, I., Indrawati, T., Aliyyah, N., Rusdiyanto, Tjaraka, H., Kalbuana, N., Rochman, A.S. (2021). The impacts of earnings volatility, net income and comprehensive income on share Price: Evidence from Indonesia Stock Exchange. Accounting, 7(5), 1009-1016.

Hapsoro, D., \& Husain, Z.F. (2019). Does sustainability report moderate the effect of financial performance on investor reaction? Evidence of Indonesian listed firms. International Journal of Business, 24(3), 308-328.

Haris, M., Yao, H., Tariq, G., Javaid, H.M., \& Ul Ain, Q. (2019). Corporate governance, political connections, and bank performance. International Journal of Financial Studies, 7(4).

Hidayat, W., Soetedjo, S., Tjaraka, H., Septiarini, D.F., Herli, M., Ulum, B., Syafii, M., Irawan, H., \& Rahayu, D.I. (2020). El efecto de la macroeconomía en los precios de las acciones: estudio de caso indonesio. Revista ESPACIOS, 41(17).

Hidayat, W., Tjaraka, H., Fitrisia, D., Fayanni, Y., Utari, W., Indrawati, M., Susanto, H., Tjahjo, J.D.W., Mufarokhah, N., \& Elan, U. (2020). The Effect of Earning per Share, Debt to Equity Ratio and Return on Assets on Stock Prices: Case Study Indonesian. Academy of Entrepreneurship Journal, 26(2), 1-10.

Indrayono, Y. (2019). Predicting returns with financial ratios: Evidence from Indonesian Stock Exchange. Management Science Letters, 9(11), 1901-1908.

Jensen, M.C., \& Meckling, W.H. (1976). Theory of The Firm: Managerial Behavior, Agency Cost And Ownership Structure. Journal of Financial Economics, 3, 305-360.

Juanamasta, I.G., Wati, N.M.N., Hendrawati, E., Wahyuni, W., Pramudianti, M., Wisnujati, N.S., ... Umanailo, M.C.B. (2019). The role of customer service through customer relationship management (Crm) to increase customer loyalty and good image. International Journal of Scientific and Technology Research, $8(10)$.

Juanamasta, I.G., Wati, N.M.N., Hendrawati, E., Wahyuni, W., Pramudianti, M., Wisnujati, N.S., Setiawati, A.P., Susetyorini, S., Elan, U., Rusdiyanto, R., Muharlisiani, L.T., \& Umanailo, M.C.B. (2019). The role of customer service through customer relationship management (Crm) to increase customer loyalty and good image. International Journal of Scientific and Technology Research, 8(10), 2004-2007.

Khoja, L., Chipulu, M., \& Jayasekera, R. (2019). Analysis of financial distress cross countries: Using macroeconomic, industrial indicators and accounting data. International Review of Financial Analysis, 66.

Kristanti, F.T., \& Iswandi. (2019). The differences of company's performance from CEO diversity [Zależność wyników firmy od różnorodności dyrektorów generalnych]. Polish Journal of Management Studies, 19(2), 240-249. 
Lamtiar, S., Arnas, Y., Rusdiyanto, A.A., Kalbuana, N., Prasetyo, B., Kurnianto, B., Saputro, R., Kurniawati, Z., \& Utami, S. (2021). Liquidity Effect, Profitability Leverage to Company Value: A Case Study Indonesia. European Journal of Molecular \& Clinical Medicine, 7(11), 2800-2822.

Le, T.N., Mai, V.A., \& Nguyen, V.C. (2020). Determinants of profitability: Evidence from construction companies listed on Vietnam Securities Market. Management Science Letters, 10(3), 523-530.

Liu, Z. (2020). Unraveling the complex relationship between environmental and financial performance, A multilevel longitudinal analysis. International Journal of Production Economics, 219, 328-340.

Lončarski, I., \& Vidovič, L. (2019). Sorting out the financials: Making economic sense out of statistical factors. Finance Research Letters, 31, 110-118.

Lussak, A., Abdurachman, E., Gautama, I., \& Setiowati, R. (2020). The influence of financial performance and innovation of services and products on the survival of small businesses in food and beverage in the Jakarta city with mediation of operational improvement. Management Science Letters, 10(2), 463-468.

Luwihono, A., Suherman, B., Sembiring, D., Rasyid, S., Kalbuana, N., Saputro, R., Prasetyo, B., Taryana, Suprihartini, Y., Asih, P., Mahfud, Z., \& Rusdiyanto. (2021). Macroeconomic effect on stock price: Evidence from Indonesia. Accounting, 7(5), 1189-1202.

Luwihono, A., Suherman, B., Sembiring, D., Rasyid, S., Kalbuana, N., Saputro, R., Prasetyo, B., Taryana, T., Suprihartini, Y., \& Asih, P. (2021). Macroeconomic effect on stock price: Evidence from Indonesia. Accounting, 7(5), 1189-1202.

Pacheco, L. (2019). Performance vs. Family ownership and management: The case of portuguese wine firms. Entrepreneurial Business and Economics Review, 7(3), 7-24.

Prabowo, B., Rochmatulaili, E., Rusdiyanto, \& Sulistyowati, E. (2020a). Corporate governance and its impact in company's stock price: case study [Gobernabilidad corporativa y su impacto en el precio de las acciones de las empresas: Estudio de caso]. Utopia y Praxis Latinoamericana, 25(Extra10), 187-196.

Prabowo, B., Rochmatulaili, E., Rusdiyanto, \& Sulistyowati, E. (2020b). Corporate governance and its impact in company's stock price: case study | Gobernabilidad corporativa y su impacto en el precio de las acciones de las empresas: Estudio de caso. Utopia y Praxis Latinoamericana, 25(Extra10), 187-196.

Rahayu, D.I., Ulum, B., Rusdiyanto, Syafii, M., Pramitasari, D.A., \& Tuharea, F.I. (2020). Fundamental impact on share prices: Evidence from indonesia. PalArch's Journal of Archaeology of Egypt/ Egyptology, 17(6), 9090-9104.

Rusdiyanto, Agustia, D., Soetedjo, S., \& Septiarini, D.F. (2020). The effect of cash turnover and receivable turnover on profitability $\mid \mathrm{El}$ efecto de la rotación de efectivo y la rotación de cuentas por cobrar en la rentabilidad. Opcion, 36(Special Ed), 1417-1432.

Rusdiyanto, H.T., Mufarokhah, N., Al'asqolaini, M.Z., Musthofa, A.J., Aji, S., \& Zainab, A.R. (2020). Corporate Social Responsibility Practices in Islamic Studies in Indonesian. Journal of Talent Development and Excellence, 12(1), 3550-3565.

Rusdiyanto, Hidayat, W., Tjaraka, H., Septiarini, D.F., Fayanni, Y., Utari, W., Waras, Indrawati, M., Susanto, H., Tjahjo, J.D.W., Zainal, M., \& Imanawati, Z. (2020). The effect of earning per share, debt to equity ratio and return on assets on stock prices: Case study Indonesian. Academy of Entrepreneurship Journal, 26(2), $1-10$.

Rusdiyanto, \& Narsa, I.M. (2019). The Effects of Earnings Volatility , Net Income and Comprehensive Income on Stock Prices on Banking Companies on the Indonesia Stock Exchange. Internasiotional Review of Manahement and Marketning, 9(6), 18-24.

Rusdiyanto, \& Narsa, I.M. (2020). The Effect of Company Size , Leverage and Return on Asset on Earnings Management : Case Study Indonesian. Espacios, 41(17), 25.

Rusdiyanto, R., Agustia, D., Soetedjo, S., Septiarini, D.F., Susetyorini, S., Elan, U., Syafii, M., Ulum, B., Suparman, P., \& Rahayu, D. I. (2019). Effects of Sales, Receivables Turnover, and Cash Flow on Liquidity.

Rusdiyanto, R., \& Narsa, I.M. (2019). The effects of earnigs volatility, net income and comprehensive income on stock prices on banking companies on the indonesia stock exchange. International Review of Management and Marketing, 9(6).

Rusdiyanto, Sawarjuwono, T., \& Tjaraka, H. (2020). Interpret The Shari' ah Accounting Practice In Indonesian. Talent Development and Excellence, 12(3), 2420-2433.

Shabbir, M.S., Mahmood, A., Setiawan, R., Nasirin, C., Rusdiyanto, R., Gazali, G., Arshad, M.A., Khan, S., \& Batool, F. (2021). Closed-loop supply chain network design with sustainability and resiliency criteria. Environmental Science and Pollution Research. 
Sharma, P., Cheng, L.T.W., \& Leung, T.Y. (2020). Impact of political connections on Chinese export firms' performance - Lessons for other emerging markets. Journal of Business Research, 106, 24-34.

Smart, N., Briggeman, B.C., Tack, J., \& Perry, E. (2019). Examining U.S. grain marketing and farm supply cooperatives' sustainable growth rates. Agribusiness, 35(4), 625-638.

Sun, J., Zhou, M., Ai, W., \& Li, H. (2019). Dynamic prediction of relative financial distress based on imbalanced data stream: from the view of one industry. Risk Management, 21(4), 215-242.

Susanto, H., Prasetyo, I., Indrawati, T., Aliyyah, N., Rusdiyanto, R., Tjaraka, H., Kalbuana, N., Rochman, A., Gazali, G., \& Zainurrafiqi, Z. (2021). The impacts of earnings volatility, net income and comprehensive income on share Price: Evidence from Indonesia Stock Exchange. Accounting, 7(5), 1009-1016.

Susanto, H., Prasetyo, I., Indrawati, T., Aliyyah, N., Rusdiyanto, Tjaraka, H., Kalbuana, N., Syafi'ur Rochman, A., Gazali, \& Zainurrafiqi. (2021). The impacts of earnings volatility, net income and comprehensive income on share price: evidence from Indonesia stock exchange. Accounting, 7(5), 1009-1016.

Syafii, M., Ulum, B., Rusdiyanto, Suparman, P., Rahayu, D.I., \& Syasindy, N.B. (2020). The effect of financial performance on the company's share price: A case study Indonesian. European Journal of Molecular and Clinical Medicine, 7(8), 1055-1071.

Tee, C.M. (2019). Institutional investors' investment preference and monitoring: evidence from Malaysia. Managerial Finance, 45(9), 1327-1346.

Till, R.E., \& Yount, M.B. (2019). Governance and Incentives: Is It Really All about the Money? Journal of Business Ethics, 159(3), 605-618.

Ulum, B., Rusdiyanto, M.S., Rahayu, D.I., \& Pramitasarisari, D.A. (2020). Profitability impact on company share prices: A case study indonesian. Solid State Technology, 63(6), 1672-1683.

Utari, W., Setiawati, R., Fauzia, N., Hidayat, W., Khadijah, S.N., Pramitasari, D.A., \& Irawan, H. (2020). The Effect of Work Discipline on the Performance of Employees in Compensation Mediation: A Case Study Indonesia. 17(9), 1056-1073.

Zainurrafiqi, Gazali, N.Q. and N.H. (2020). The Effect Of Organization Learning Capability And Organizational Innovation On Competitive Advantage And Business Performance. Russian Journal of Agricultural and Socio-Economic Sciences (RJOAS), 3(99), 9-17.

Zainurrafiqi , Racawati, R., Putri, D.L.P., Resdiana, E., Widyastuti, E., Asy'ari, Q., Rusdiyanto, W.H. (2020). The Determinants And Consequents Of Competitive Advantage Based Of Local Wisdom At The Micro, Small, And Medium Enterprise : Evidence From Indonesia. Solid State Technology, 63(6), 1604-1620. 